\title{
A social work study on measuring the effects of culturing factors influencing consumerism
}

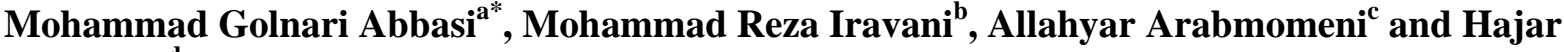 \\ Jannesari $^{d}$
}

\author{
${ }^{a}$ Islamic Azad University of Khomeinishahr, Department of Economic, Islamic Azad University Khomeinishahr Branch, Daneshjou Blvd, Iran. \\ ${ }^{b}$ Assistant Professor, Department of Social Work, Islamic Azad University, Khomeinishahr Branch, Daneshjou Blvd, Isfahan, Iran \\ ${ }^{c}$ Department of Human Science of Islamic Azad University Khomeinishahr Branch, Isfahan, Iran \\ ${ }^{d}$ MS Student, Counseling Department, Islamic Azad University of Khomeinishahr, Khomeinishahr Branch, Daneshjou Blvd, Iran \\ C H R O N I C L E

\section{A B S T R A C T}

Article history:

Received December 2, 2012

Received in revised format

2 March 2013

Accepted 5 March 2013

Available online

April 302013

Keywords:

Consumerism

Social work study
This paper presents a social work study to measure the impact of various cultural factors on consumerism in city of Esfahan, Iran. The proposed study uses clustering technique to choose a sample of 300 families out of 70,000 residences of this city. The study designs a questionnaire in Likert scale and distributes it among participants. Cronbach alpha have been calculated as 0.85 and 0.92 for cultural factors and consumerism, respectively. The results of Pearson correlation ratios indicate that there are statistically meaningful relationships between consumerism and four components of culture including religious believes, tendency to luxuries, using different multi medias and adherence to traditions.

\section{Introduction}

Consumerism is one of the most important issues among under developed or developing countries. The people who live in these countries do not produce value added but they consume as much as they could. This means more imports and less export and damages the economy, severely (Bauman, 2004; Campell, 2005). Many people believe there is a relationship between self-identity and behavioral intentions independent of the role of attitudes (Sparks \& Shepherd, 1992; Micheletti et al., 2004). According to Lupton (1997), there are growing concerns in sociological, policy and popular discourses on changes in lay people's behaviors towards the medical profession labeled as a move towards the embracing of "consumerism". Consumerism assumes that lay people act as "rational" actors within the context of the medical encounter and they align with broader sociological concepts of the "reflexive self" as a product of late modernity; that is, the self who acts in a manner to involve in self-improvement and who is skeptical about expert knowledge. To explore the methods that

Corresponding author. Tel: + 989133091178

E-mail: Golnari@iaukhsh.ac.ir (M. Golnari Abbasi)

(C) 2013 Growing Science Ltd. All rights reserved.

doi: 10.5267/j.msl.2013.04.030 
people think and feel about medicine and the medical profession, Lupton (1997) performed an investigation involving in-depth interviews with 60 lay people from a wide range of backgrounds living in Sydney. The study concluded that late modernist notions of reflexivity as applied to issues of consumerism could fail to recognize the complexity and changeable nature of the desires, emotions and requirements, which characterize the patient-doctor relationship.

Strong (1996) studied features contributing to the growth of ethical consumerism-a preliminary investigation. According to Bird et al. (2002), consumer concern for "ethical products", or ethical perspectives of the goods people buy, is a subject of increasing interest and they investigated this issue by an examination of the Fair Trade movement, with special relationship with coffee as an indicative commodity. According to Potter (2007), consumerism tries to redress the imbalance of power, which exists between those who produce goods and services, and those use them. To reach this end, five primary principles have been emerged, which look for improvement of consumers' access, choice, information, redress and representation. Potter (2007) examined the relevance of these objectives to services provided by local government and the health service and concluded that they were useful but not necessarily sufficient. Potter also considered whether the messages of consumerism were reaching their mark, and finally pointed to those issues, which managers of public services. According to Barnes and Prior (1995) sociological discussions of the characteristics of contemporary social life, recommends that prioritizing individual choice could have disempowering consequences for public service users, generating confusion, uncertainty and stress. A better alternative could be to develop tools of strengthening users' impact over the shape and content of services. These days, many people blame consumerism as a primary reason for global warming and propose new efforts for having green consumerism.

Moisander (2007) evaluated on the motivational complexity of green consumerism based on a simple model of motivation as an analytical tool. The purpose of the survey was to shed light into the challenges that environmentally concerned 'green consumers' may face in the markets. In addition, the study explained the limitations of framing and targeting environmental policy measures in terms of individual motivation and argued that as a private lifestyle project of a single individual, 'green consumerism' could be much too heavy a responsibility to bear. Eriksson (2004) tried to see whether green consumerism replace environmental regulation. Eriksson (2004) assumed that consumers would be willing to pay an extra premium for a commodity if it had a low impact on the environment and examined whether a little dose of such idealistic behavior had a large influence on the market equilibrium. The survey green consumerism will only be modestly influential in both cases. According to Pedersen and Neergaard (2006) the idea of the 'green' consumer is over-simplified and could fail to capture the actual complexity of consumer values, attitudes and behavior.

This paper presents a social work study to measure the impact of various cultural factors on consumerism in city of Esfahan, Iran. The organization of this paper first presents the proposed study in section 2 and section 3 gives details of our findings. Finally, concluding remarks are given in the last to summarize the contribution of the paper.

\section{The proposed study}

This paper presents a social work study to measure the impact of various cultural factors on consumerism in city of Esfahan, Iran. The proposed study uses clustering technique to choose a sample of 300 families out of 70,000 residences of this city. The study designs a questionnaire in Likert scale and distributes it among participants. In our survey, $37.5 \%$ of the participants were male and the remaining $62.5 \%$ of them were female. In terms of educational backgrounds, $24.7 \%$ only finished high schools, $14.2 \%$ of them could manage to finish a two-year college, $44.7 \%$ of them hold bachelor degrees, $11.4 \%$ of them had masters' degrees and finally, $5 \%$ of the people who participated in our survey maintained $\mathrm{PhD}$ degree. In addition, Fig. 1 demonstrates the frequencies of the participants in terms of their age backgrounds. As we can observe from the results of Fig. 1, more participants were middle aged people and only $18.2 \%$ of them were young. According to the results of Fig. 2, most participants hold average salaries between 800,000 to 10 million Rials per month. 
Note that this range of salary is considered low income and depending on various rate of exchange, this represents approximately $400-800 \$$ per month salary.

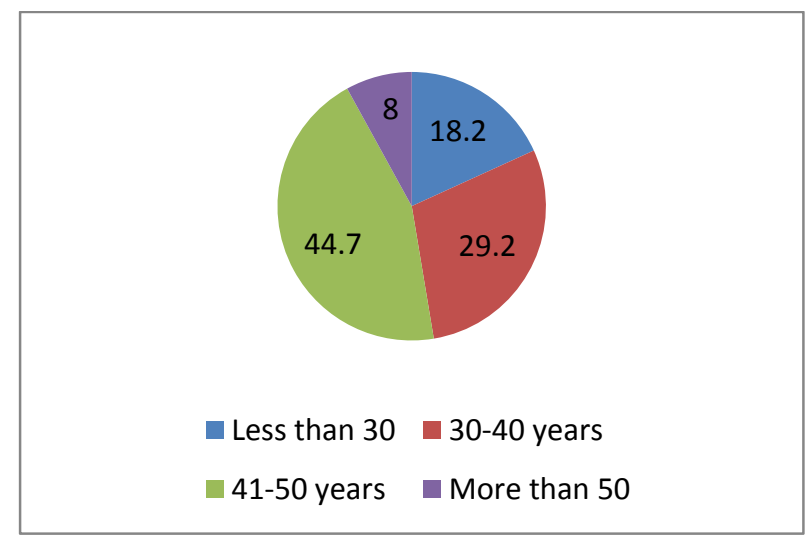

Fig. 1. The frequencies of age perspectives

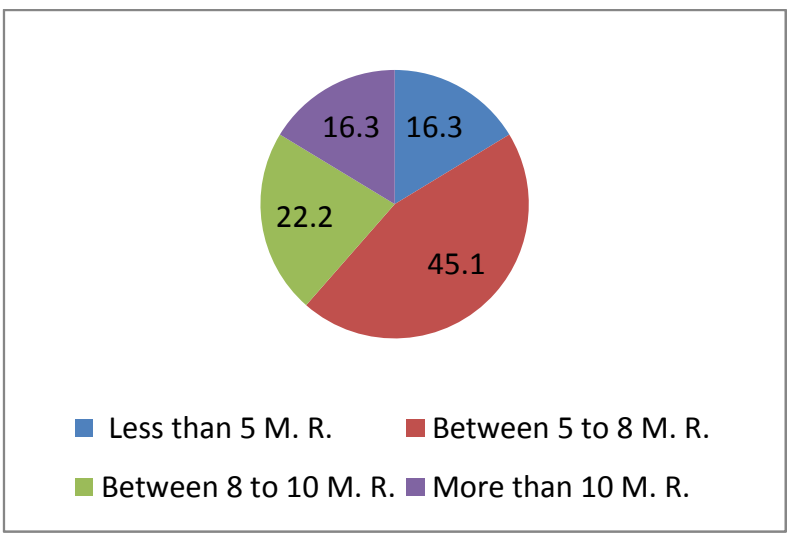

Fig. 2. People’s income in terms of Million Rials

The proposed study of this paper considers four hypotheses as follows,

1. There is a relationship between consumerism and religious believes.

2. There is a relationship between consumerism and tendency to luxuries.

3. There is a relationship between consumerism and watching different multi medias.

4. There is a relationship between consumerism and adherence to traditions.

Cronbach alpha have been calculated as 0.85 and 0.92 for cultural factors and consumerism, respectively.

\section{The results}

In this section, we present details of our survey on testing four hypotheses of this survey.

\subsection{The first hypothesis: The relationship between consumerism and religious believes}

The result of the implementation of Pearson correlation ratio between consumerism and religious believes yields 0.645 and $\mathrm{P}$-value is equal to 0.001. Therefore, we can conclude that there is meaningful relationship between these two components when the level of significance is five or even one percent.

\subsection{The second hypothesis: The relationship between consumerism and tendency to luxuries}

The result of the implementation of Pearson correlation ratio between consumerism and religious believes yields 0.645 and P-value is equal to 0.001. Therefore, we can conclude that there is meaningful relationship between these two components when the level of significance is five or even one percent.

\subsection{The third hypothesis: The relationship between consumerism and watching different multi medias}

The result of the implementation of Pearson correlation ratio between consumerism and religious believes yields 0.372 and $\mathrm{P}$-value is equal to 0.001 . Therefore, we can conclude that there is meaningful relationship between these two components when the level of significance is five or even one percent.

\subsection{The fourth hypothesis: The relationship between consumerism and adherence to traditions}

The result of the implementation of Pearson correlation ratio between consumerism and religious believes yields 0.270 and P-value is equal to 0.001 . Therefore, we can conclude that there is 
meaningful relationship between these two components when the level of significance is five or even one percent.

The proposed study of this paper uses a regression analysis to investigate the relationship between consumerism as dependent variable $(\mathrm{Y})$ and independent variables and using stepwise regression analysis we have obtained the following results.

$$
Y=64.46+3.76 \text { tendency to luxuries }-0.757 \text { religious believes }+0.962 \text { adherence to traditions }
$$

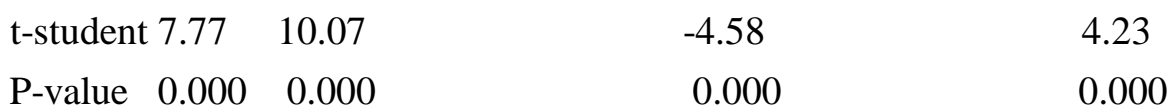

The results of regression analysis explain that an increase in tendency to luxuries as well as adherence to traditions may increase consumerism but people who are more religious tend to stay away from consumerism.

\section{Conclusion}

In this paper, we have presented an empirical investigation on learning the effects of different factors on consumerism. The results of our survey have indicated that there were positive correlations between consumerism and four components of culture including religious believes, tendency to luxuries, using different multi medias and adherence to traditions. In addition, the results of regression analysis have indicated that an increase in tendency to luxuries as well as adherence to traditions may increase consumerism but people who are more religious tend to stay away from consumerism.

\section{Acknowledgment}

The authors would like to thank the anonymous referees for constructive comments on earlier version of this paper.

\section{References}

Barnes, M., \& Prior, D. (1995). Spoilt for choice? How consumerism can disempower public service users. Public Money \& Management, 15(3), 53-58.

Bauman, Z. (2004). Work, consumerism and the new poor. Open University Press.

Bird, K., \& Hughes, D. R. (2002). Ethical consumerism: The case of "Fairly-Traded" coffee. Business Ethics: A European Review, 6(3), 159-167.

Campbell, C. (2005). The romantic ethic and the spirit of modern consumerism. WritersPrintShop.

Eriksson, C. (2004). Can green consumerism replace environmental regulation?-a differentiatedproducts example. Resource and energy economics, 26(3), 281-293.

Lupton, D. (1997). Consumerism, reflexivity and the medical encounter. Social Science \& Medicine, 45(3), 373-381.

Micheletti, M., Føllesdal, A., \& Stolle, D. (2004). Politics, products, and markets: Exploring political consumerism past and present. Transaction Pub.

Moisander, J. (2007). Motivational complexity of green consumerism. International Journal of Consumer Studies, 31(4), 404-409.

Pedersen, E. R., \& Neergaard, P. (2006). Caveat emptor-let the buyer beware! Environmental labelling and the limitations of 'green' consumerism. Business Strategy and the Environment, 15(1), 15-29.

Potter, J. (2007). Consumerism and the public sector: how well does the coat fit?. Public Administration, 66(2), 149-164.

Sparks, P., \& Shepherd, R. (1992). Self-identity and the theory of planned behavior: Assesing the role of identification with “Green Consumerism”. Social Psychology Quarterly, 388-399.

Strong, C. (1996). Features contributing to the growth of ethical consumerism-a preliminary investigation. Marketing Intelligence \& Planning, 14(5), 5-13. 